\title{
Natural Disasters and Countermeasures for the Tokyo Lowland
}

\author{
Iware MATSUDA
}

\begin{abstract}
The Tokyo Lowland has suffered from natural disasters several times, because thick soft ground is developed over a broad area and the ground height is low. In addition, land below sea level came into existence during the 1930's due to land subsidence and continued to expand. It now covers about $68 \mathrm{~km}^{2}$.

The Great Kanto Earthquake brought the largest damage ever caused by a natural disaster in Japan. Fires were to blame for the majority of lost lives and destoyed houses in the Tokyo Lowland. As a result, countermeasures for fires have been regarded as most important against an earthquake. The Tokyo Lowland has suffered from three separate types of flood disaster: due to the collapse of river banks, storm surges and inland waters. Also, there is a risk of flood disaster induced by an earthquake.

Two characteristics are remarkable in the Tokyo Metropolitan Government's policy for urban disaster prevention. One is that disaster-proof city planning should be based on security, but works for an emergency should fit in with everyday life. The other is that construction of disaster prevention facilities should be based on the long-term urban development plan. These have been well realized in the several kinds of countermeasures undertaken in and around the Koto District, especially in construction of the Shirahige Higashi Disaster Prevention Base.

By examining relationships among land conditions, landuse, natural disasters and countermeasures on the Tokyo Lowland, it is proven that artificial changes to the natural conditions and landuse done in past become the threshold conditions for improvement works in the future.
\end{abstract}

Key words: Tokyo Lowland, natural disaster, land subsidence, countermeasures, disaster prevention base, disaster-proof city planning.

\section{INTRODUCTION}

Most of the large cities in Japan are located on plains. These plains were formed at the end of the Quaternary, and are composed of terraces and lowlands. Although the total area of lowland accounts for only about $13 \%$ of the national land, half the total population and more than $70 \%$ of the nation's property are concentrated there (Ministry of Construction, 1985). Tokyo is located on the southern part of the Kanto Plain. The lowland was urbanized earlier than the terraces in Tokyo. This pattern of urbanization has occurred in other Japanese cities.

In the past, Tokyo has frequently experienced earthquakes and inundation by storm surges and flood waters. The experiences of past natural disasters have revealed a number of problems. They are as follows:

Natural conditions;

(1) Because thick soft ground is developed over broad area, the Tokyo Lowland is likely to be damaged in an earthquake by both the impact of ground motion and liquefaction of loose sandy deposits;

(2) In addition to the fact that the original ground height of the Tokyo Lowland was low, and subsidence has resulted in a lower ground height and given rise to land below sea level;

Social conditions;

(1) With the exception of the commercial and business districts, most of the built-up areas are composed of wooden houses built relatively close together;

(2) Roads in the residential areas are narrow, and open spaces are scarce;

(3) There are many urban facilities which have

*Department of Geography, Tokyo Metropolitan University, Fukazawa, Setagaya-ku, Tokyo 158 
not yet experienced a strong earthquake, such as skyscrapers, underground complexes, highways and so on;

(4) The central management functions for administration and economic activities tend to be concentrated in this area;

(5) Many people have to commute long distances from suburban areas to their place of work and study;

(6) The concentration of population, urban facilities and economic functions means that it would be difficult to cope with the damage that would result from a big earthquake.

By focusing on the Tokyo Lowland, which has been subjected to natural disasters several times, this paper will discuss land conditions, landuse, natural disasters and countermeasures.

\section{LAND CONDITIONS OF THE TOKYO LOWLAND}

\section{Landforms and subsurface geology}

Topographic conditions of Tokyo are characterized by two different landforms; the Yamanote Upland and the Tokyo Lowland. The Yamanote Upland is 20 to $50 \mathrm{~m}$ in height and consists of terraces. The highest terrace is a coastal plain which was formed during the last interglacial age. Lower terraces are composed of alluvial fans which dissected the highest terrace as sea level lowered toward the last glacial age.

The Tokyo Lowland was one of the inlets which were located around Tokyo Bay 6,000 years B.P. at the highest stage of sea level of the postglacial transgression. The inlet was buried by deltaic deposits supplied by the Ara River, Tone River and also other rivers. In addition, the southern part of the Tokyo Lowland was enlarged by reclamation after the 16 th century. Because the Tokyo Lowland is composed of a deltaic lowland and reclaimed land, its original ground height is less than $2 \mathrm{~m}$.

The deltaic materials deposited in the inlet are of Recent geological age, which means the latest Pleistocene to Holocene strata formed after the lowest stand of sea level between 15,000 and 20,000 years B.P. They are divided into two members, upper and lower, by a sandy interca- lation at a depth of 20 to $40 \mathrm{~m}$. Lithofacies of the lower member are characterized by alternate layers of sand and clay. In contrast, the upper member is composed of a homogeneous thick clayey layer overlain by a sandy layer. The clayey layer is very soft and the sandy layer is loose.

The thickness and the lithofacies of the Recent formation are affected by the buried topography beneath them. The buried topography can be classified into three types; two buried abrasion platforms, $10 \mathrm{~m}$ and 20 to $30 \mathrm{~m}$ in depth; two buried river terraces, $30 \mathrm{~m}$ and 40 to $50 \mathrm{~m}$ in depth; and a buried valley floor 60 to $70 \mathrm{~m}$ in depth. The deepest buried valley floor is located in the central part of the Tokyo Lowland whilst the buried abrasion platforms fringe the uplands. The buried river terraces develop between the buried valley floors and the buried abrasion platforms. That is, the Recent formation is thickest in the central part of the Tokyo Lowland and becomes thinner toward the periphery.

Detailed discussion on the sedimentary history and distribution of the Recent formation around Tokyo Bay was done by MATSudA (1974) and KAIzUKA et al. (19.77).

Three big rivers flow over the Tokyo Lowland and into Tokyo Bay. One is the Ara River and the other two are the Naka and Edo Rivers. The lowest reach of the Ara River is called the Sumida River. The Naka and Edo Rivers were the lower reach of the Tone River until 1621, when the flow in the Tone River was directed east to the Pacific Ocean (Matsuura, 1989). Figure 1 shows rivers and canals on the Tokyo Lowland in the 1880's. Several sheets of the "Jinsokuzu", which was the first formal topograhic map published in Japan, were consulted to make the figure.

The Imperial Palace, which was the former Edo Castle, is located at the eastern edge of the Yamanote Upland. A densely built-up area developed along the Sumida River and was composed of residential wooden houses and facilities for commercial activities. A network of canals existed for ship transportation. Most of the Tokyo Lowland was used for agriculture. Paddy fields occupied a broad area along with scattered small villages. 


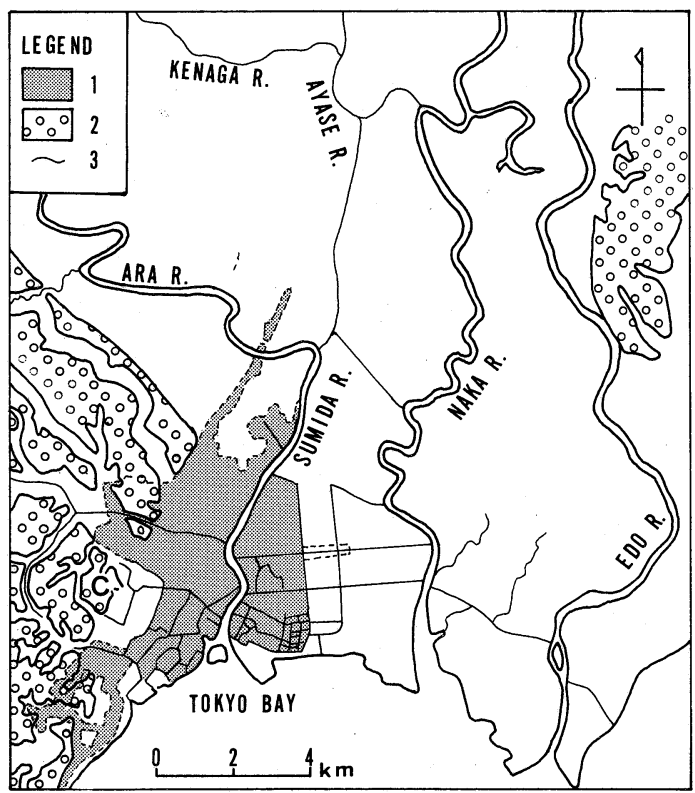

Figure 1. Tokyo Lowland in the 1880's.

1: Densely built-up area; 2: Yamanote Upland (west), Shimofusa Upland (east); 3: Small rivers and canals.

C: Imperial Palace

\section{Lowering of the ground height due to land subsidence}

Rapid industrialization began to take place on the Lowland from the end of the 19th century. Many factories for the machine industry, the chemical industry, dyeing and textile industries, etc. were built. As shipping was the main means for transportation, factories were located along the Ara River and the canals between the Sumida and Naka Rivers (TAKEMI, 1930). As industrialization increased, it spread toward the north.

As groundwater use by these factories increased in amount, land subsidence took place. The pattern of land subsidence on the Tokyo Lowland can be seen in Figs. 2 and 3. The no. 3377 bench-mark was lowered a total of $170 \mathrm{~mm}$ in the period 1892 to 1916 . The mean annual value of subsidence during this period was $7 \mathrm{~mm}$. Since the amount of natural subsidence of the ground surface due to crustal movement and compaction of the soft Recent formation is usually less than 3 or $4 \mathrm{~mm} /$ year, it can be said that artificial land subsidence due to the withdrawal of groundwater began before 1916. Af-

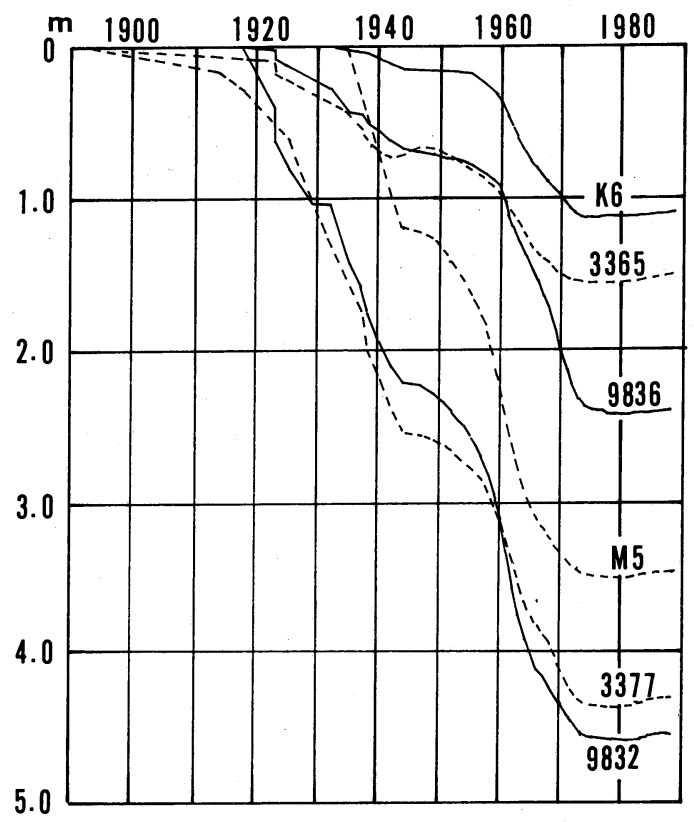

Figure 2. Accumulated amount of subsidence of bench-marks.

Data source: IsHil, et al. (1988)

Location of bench-marks is shown in Fig. 3.

ter 1916, the process of land subsidence was accelerated. The accumulated amount of land subsidence at the no. 9832 bench-mark exceeded $2 \mathrm{~m}$ by 1935 . The land below sea level originated during the 1930's, because the original ground height of the Tokyo Lowland was less than $2 \mathrm{~m}$ above sea level (NAKANO and MATSUDA, 1976).

Rapid land subsidence continued until the end of the Second World War. But bench-marks nos. 3365,9836 and K6 show that land subsidence was less conspicuous in the northern and eastern parts of the Tokyo Lowland than in the central part during these years.

Tokyo suffered from bombing during the Second World War and its industrial regions were destroyed. Consequently, withdrawal of groundwater decreased in amount and land subsidence ceased. However, as the industrial regions were reconstructed after the War, the land surface began to subside again. Land subsidence became faster after 1950 and an area of $74 \mathrm{~km}^{2}$ subsided more than $100 \mathrm{~mm}$ during 1961 (NAKANO et al., 1969).

Control of groundwater use was taken into ac- 
count and regulation of groundwater withdrawal began in 1961. Land subsidence began to decrease in 1965 and had stopped altogether by about 1975. Some bench-marks, however, had subsided more than $4 \mathrm{~m}$ in total, and the area of land below sea level had become quite extensive.

Figure 3 shows the ground height of the Tokyo Lowland. As the mean sea level of Tokyo Bay is used for the datum plane, $0 \mathrm{~m}$ relates to the mean sea level, and $+1 \mathrm{~m}$ and $-1 \mathrm{~m}$ are the flood tide level and the ebb tide level respectively. The land below sea level came into existence during the 1930's and continued to expand gradually in the central part of the Tokyo Lowland. The land below sea level now covers about $68 \mathrm{~km}^{2}$. About half the area of the land below sea level is lower than the mean level of ebb tide. The land below flood tide level along the Ara River (formerly the Ara River Drainage Canal) from its mouth is $6-10 \mathrm{~km}$ in width and $124 \mathrm{~km}^{2}$ in area.

The large area of land below sea level has come to be a troublesome threshold condition for disaster prevention projects on the Tokyo Lowland area.

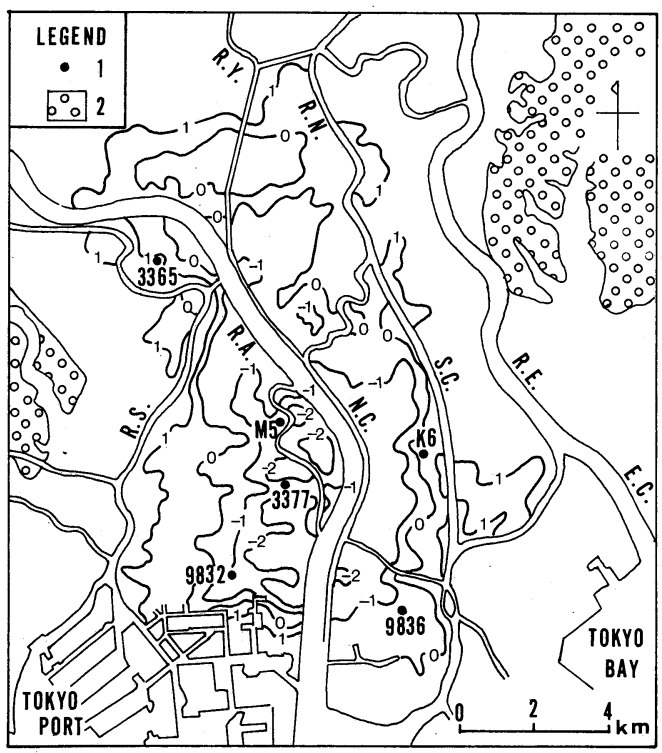

Figure 3. Ground height of the Tokyo Lowland. 1: Bench-marks shown in Fig. 2; 2: Uplands; Rivers - R.A.: Arakawa River; R.E.: Edo River; R.N.: Naka River; R.S.: Sumida River; R.Y.: Ayase River; Canals - N.C.: Naka River Drainage Canal; S.C.: Shinnakagawa Drainage Canal; E.C.: Edo River Drainage Canal.

\section{A SHORT HISTORY OF NATURAL DISASTERS IN TOKYO}

\section{Earthquake disasters}

UsAmI (1976) detected 37 earthquakes which shook Tokyo at an intensity of 5 or more on the Japan Meteorological Agency (JMA) Scale between 1595 and 1975. An intensity of 5 on the JMA Scale is nearly equal to that of 8 on the Modified Mercalli's Scale. Among the 37 earthquakes, the 6 earthquakes of $1615,1649,1703$ (the Genroku Earthquake), 1855 (the Ansei Edo Earthquake), 1894 and 1923 (the Great Kanto Earthquake) respectively recoreded an intensity of 6 on the JMA Scale and caused deaths, injuries and destruction of buildings (Table 1).

Major earthquakes in the Kanto area usually originate in and around the transform fault along the eastern edge of the Sagami Trough, which stretches from Sagami Bay to the waters south of the Boso Peninsula. The magnitude (M) of the Genroku Earthquake of 1703 was 8.2 on the Richter Scale and that of the Great Kanto Earthquake was 7.9. These earthquakes are called "transform fault type earthquakes".

The Ansei Edo Earthquake $(M=6.9)$, and the earthquakes of $1615(\mathrm{M}=6.4), 1649(\mathrm{M}=7.1)$ and $1894(\mathrm{M}=7.0)$ were less in intensity than the transform fault type earthquakes. Nonetheless, they inflicted devastating damage on Tokyo because their foci were directly under the metropolis. Such earthquakes are called "direct-hit type earthquakes” (NAKANO and Matsuda, 1984).

Damage was especially extensive in the Ansei Edo Earthquake of 1855 and the Great Kanto Earthquake of 1923. About $10 \%$ of dwelling houses were destroyed and the number of people who were crushed to death by collapsed structures reached about 10,000 in 1855 . About 50 fires broke out and burnt 220 ha of a city area. The victims of fires, however, were not large in number (TAJIME et al., 1977).

The Great Kanto Earthquake claimed the largest number of deaths and damage ever caused by a natural disaster in Japan. While the total number of dead and missing reached about 143,000 , about 104,000 people were listed as injured. Approximately 128,000 structures were 
Table 1. Earthquakes that have shaken Tokyo at the intensity of VI on the JMA Scale since 1600.

\begin{tabular}{ccccr}
\hline \hline Date of Occurrence & Type & Magnitude (M) & Number of Dead & Number of Lost Houses \\
\hline 26. 6.1615. & D.H.T. & 6.4 & Many & Many \\
30. 7.1649. & D.H.T. & 7.1 & Many & Many \\
31.12.1703. & T.F.T. & 8.4 & Many & Many \\
11.11 .1855$. & D.H.T. & 6.9 & ca. 14,000 & ca. 10,000 \\
20. 6.1894. & D.H.T. & 7.0 & 60,120 & 370,148 \\
1.9 .1923$. & T.F.T. & 7.9 &
\end{tabular}

D.H.T.: direct-hit type; T.F.T.: trnasform fault type.

Number of dead and lost houses are recorded in the old Tokyo City area only.

Data source: UsAmı (1976) and Imperial Earthquake Investigation Committee (1925a).

demolished by the shock and as many as 447,000 structures were lost in fires (Imperial Earthquake Investigation Committee, 1925a).

Tokyo was especially damaged by fires. Soon after the shock, 129 fires broke out simultaneously, and 76 of which spread over large area. They continued to rage for 40 hours, scorching $44 \%$ of the city area. About 60,000 people $(2.4 \%$ of the total population of Tokyo City) were lost, and about 366,000 dwelling houses were burnt out. Fires were to blame for $98 \%$ of destroyed houses.

The causes of death were clarified for 58,481 persons. The majority, $89.2 \%$, were burnt to death. Although $9.2 \%$ of them were drowned, most of the drowned persons dived into the water in order to escape from the fires. The number of people who were crushed to death was only 788 , equaling 1.3\% (Imperial Earthquake Investigation Committee, 1925b).
In the earthquakes of 1855 and 1923, damage was extensive because of the fires that followed. A distinction must be made, however, between the two earthquakes. In the case of the 1855 earthquake, the destruction of houses and deaths were due more to the direct impact of ground motion than to fires. On the other hand, fires were the chief cause of the destruction and deaths in the 1923 earthquake. This is the main reason why countermeasures for fires are regarded as most important against an earthquake.

\section{Flood disaster}

The Tokyo Lowland has suffered from three separate types of flood disaster (Table 2). The first type of flood disaster is caused by the collapse of river banks. The three biggest floods of the Edo Period of 1742, 1786 and 1846 are well documented. Also, the flood disasters of 1910 and 1947 are typical examples. The banks of

Table 2. Main flood disasters in Tokyo since 1910.

\begin{tabular}{|c|c|c|c|c|c|c|c|}
\hline $\begin{array}{c}\text { Date of } \\
\text { Occurrence }\end{array}$ & $\begin{array}{c}\text { Total } \\
\text { Rainfall }\end{array}$ & $\begin{array}{l}\text { Highest } \\
\text { Tide Level }\end{array}$ & $\begin{array}{c}\text { Type of } \\
\text { Main Flood }\end{array}$ & $\begin{array}{c}\text { Inundated } \\
\text { Area }\end{array}$ & $\begin{array}{c}\text { Number of } \\
\text { Inundated } \\
\text { Houses }\end{array}$ & $\begin{array}{l}\text { Number of } \\
\text { Lost Houses }\end{array}$ & $\begin{array}{l}\text { Number } \\
\text { of Dead }\end{array}$ \\
\hline 9. 8.1910 . & $283.9 \mathrm{~mm}$ & - & River flood & 20,143 ha & 178,057 & 27,594 & 176 \\
\hline 30.10 .1917 & 161.6 & T.P. $3.08 \mathrm{~m}$ & Storm surge & 8,660 & 180,338 & 1,257 & 563 \\
\hline 31. 8.1938. & 144.1 & 1.76 & Storm surge & 7,790 & 108,570 & 402 & 11 \\
\hline 14. 9.1947 . & 166.8 & 1.37 & River flood & 9,206 & 103,872 & 110 & 8 \\
\hline 16. 9.1948 . & 158.0 & 1.52 & River flood & 3,907 & 17,346 & 78 & 2 \\
\hline 1. 9.1949 . & 64.9 & 2.02 & Storm surge & 9,201 & 137,877 & 896 & 18 \\
\hline 23. 7.1958 . & 108.5 & 1.76 & Storm surge & 2,946 & 36,429 & 385 & 3 \\
\hline 24. 9.1958 . & 444.1 & 1.78 & Inland waters & 21,103 & 480,533 & 372 & 39 \\
\hline 27. 6.1966 . & 235.0 & - & Inland waters & 8,762 & 101,794 & 25 & 8 \\
\hline 30. 8.1971. & 181.0 & - & Inland waters & 730 & 6,446 & 0 & 2 \\
\hline 19.10.1979. & 251.0 & 2.42 & Inland waters & 147 & 1,730 & 33 & 6 \\
\hline 23.10 .1981 & 221.0 & 0.73 & Inland waters & 1,959 & 42,021 & 1 & 0 \\
\hline 4. 8.1986 . & 264.0 & - & Inland waters & 860 & 6,163 & 0 & 0 \\
\hline
\end{tabular}

Data source: Tokyo Metropolitan Government (1987).

T.P. means Tokyo Peil which is the mean sea level of Tokyo Bay. 
either or both the Tone and Ara Rivers collapsed in all cases.

The banks of both the Tone River and the Ara River collapsed in several places in 1910. Flood water poured onto the Tokyo Lowland from the north along the Edo, Ayase and Naka Rivers, and from the west along the Ara River. An area of about $201 \mathrm{~km}^{2}$ was inundated on the Tokyo Lowland. The numbers of lives lost reached 176, and the number of houses 27,594. This disaster was the most extensive flood event since the beginning of the Meiji Era (Tokyo Metropolitan Government, 1987).

Flood disasters due to storm surges driven by typhoon are the second type. When a strong typhoon passes to the west of Tokyo, a high storm surge usually strikes the coast of the Tokyo Lowland. Eight storm surges have damaged the Tokyo Lowland since 1910 . They were brought by the typhoons of 1911, 1917, 1921, 1927, 1938, 1949, 1953 and 1958. In 1917, a high tide level of $3.08 \mathrm{~m}$ above the mean sea level of Tokyo Bay was recorded. In the southern part of the Tokyo Lowland an area of $86.6 \mathrm{~km}^{2}$ was inundated, and 563 lives were lost. The number of houses inunated by flood waters reached 180,338 , and 1,257 houses were swept away (Tokyo Metropolitan Government, 1987).

As mentioned in the previous chaper, the Tokyo Lowland has been affected by land subsidence and the land below sea level occupies an area of about $68 \mathrm{~km}^{2}$. Because the ground height is lower than the water level of rivers and canals in this area, rain water does not drain away well. Consequently, during a torrential rainfall in this area, inundation occurs. Such a flood disaster is the third type, and is referred to as a "flood disaster caused by inland waters". This type of flood disaster will occur not only on the land below sea level but also on the areas where poor drainage facilities are presented.

The Kanogawa Typhoon of 1958 brought rainfall of $76.0 \mathrm{~mm} /$ hour and a total of $444.1 \mathrm{~mm}$ of rainfall on Tokyo. Inland waters flooded not only the Tokyo Lowland but also valley flats in the Yamanote Upland. As a result, an area of $211 \mathrm{~km}^{2}$ was inundated with 480,533 houses flooded out (Tokyo Metropolitan Government, 1987).

The Tokyo Lowland is vulnerable to one more type of flood disaster, that is, a flood disaster induced by an earthquake. Although the Tokyo Lowland has not been struck by this type of flood, it is a possibility because of the land area below sea level. When the Niigata Earthquake of 1964 struck Niigata City, the banks of the Shinano River were broken through liquefaction of sandy ground. Since Niigata City had been affected by land subsidence, the ground height of the southern part of the city was below sea level. Waters of the Shinano River flowed into this area and an inlet was formed. As the tide level changed, so the water level in the inlet varied. If Tokyo was hit by a big earthquake, several river banks could collapse through liquefaction of sandy ground, with the result that a tidal inlet would be formed in the central part of the Tokyo Lowland as occurred in Niigata City in 1964.

\section{THE URBAN DISASTER PREVENTION PROJECT}

\section{Countermeasures for flood disasters}

Countermeasures for flood disasters were a main subject for urban disaster prevention works until Niigata City was damaged by the Niigata Earthquake of 1964. Construction of the Ara River Drainage Canal (presently the Ara River) and the "gaikaku teibo", which means a fringing bank, was the most important among the disaster prevention works carried out on the Tokyo Lowland. These two facilities have had much effects of preventing flood disasters.

The flood disaster of 1907 and 1910 promoted the construction of the Ara River Drainage Canal, because newly developed industrial and residential areas were heavily damaged. Agricultural landuse has been replaced by urban landuse in the central and northern parts of the Tokyo Lowland since the end of the 19th century.

Construction work of the Ara River Drainage Canal was started in 1911 and was completed in 1930. Because the Ara River Drainage Canal was to be aligned across the Naka and Ayase Rivers, the Ayase River was connected to the newly constructed Naka River Drainage Canal (Fig. 3). The Ara River Drainage Canal has its official name changed to the Ara River in 1956. 
The Ara River Drainage Canal prevents flooding of the Sumida River and acts as a barrier for flood waters from the Tone River. Since the risk of a flood disaster has been significantly decreased, many new factories have been constructed on the right bank area adjacent to the Ara River Drainage Canal, increasing the rate of land subsidence.

Because the Ara River Drainage Canal has a dramatic effect on flood prevention together with other drainage canals, the Tokyo Lowland has not been damaged by a river flood since the Tone River flooded in 1947. The left bank of the Ara River Drainage Canal acted as a barrier during this flood disaster, saving the right bank area from inundation.

The Tokyo Metropolitan Government (TMG) prepared the Comprehensive Storm Surge Prevention Project in 1934. Although the work for storm surge prevention was interrupted by the Second World War, it was almost finished by 1956 . After that, because land subsidence has lowered the height of banks, improvement work has become necessary.

It was adopted as a permanent countermeasure against a storm surge that high breakwaters be constructed along the coast of Tokyo Bay, and that the banks of the major rivers be strengthened. These high breakwaters and banks are called the "gaikaku teibo". The Koto District has become enclosed by the high banks of the Sumida and Ara Rivers, and the high breakwater around the reclaimed land (Fig. 4).

The design level of the high tide adopted in this project was initially $3.08 \mathrm{~m}$ above the mean sea level of Tokyo Bay (this was the level recorded by the storm surge of 1917). When the coastal region of the Nobi Plain was seriously damaged with a storm surge driven by the Isewan Typhoon of 1959, the maximum tide level was equivalent to $3.97 \mathrm{~m}$ above the mean sea level of Tokyo Bay. Thus the design level of high tide was subsequently altered to this high level.

Construction of the "gaikaku teibo" has almost been completed on the Tokyo Lowland. Although a high tide level of $2.42 \mathrm{~m}$ was recorded in 1979, the Tokyo Lowland was not affected. It has not been flooded by a storm surge since 1958 (Table 2).

At the same time as construction of the "gai- kaku teibo", several water gates have been constructed to prevent sea and river waters from invading into canals and rivers during a flood tide. Also, draining sites have been constructed (Fig. 4). These sites are able to drain rainfall of up to $40 \mathrm{~mm} /$ hour away from the Koto District.

As a result the likelihood of a flood disaster due to inland waters has been decreased considerably. Countermeasures for one more type of flood disaster have also been necessary. Countermeasures for an earthquake induced flood have been taken together with general improvement of the living environment. After the Redevelopment Plan for the Koto District (RPKD) was drawn up in 1969, the Koto District River Improvement Works were started in 1971. In this project, an improvement design for the canals and rivers in the Koto District was implemented.

Because the ground height was higher than the water level and the canals were useful for ship transportation in the western part of the Koto District, the river walls were strengthened to withstand an earthquake. In the eastern part where the ground height was lower than the water level, the water level was lowered to below the ebb tide level and canal widths were reduced. The canals which were less effective for draining rain water away were filled in or changed to a culvert (Fig. 4).

The risk of a flood disaster caused by inland waters or an earthquake has been decreased significantly by these improvements. The land produced by these works is used for parks and as secure open spaces, and has resulted in a general improvement in the living environment.

\section{Countermeasures for earthquake disasters}

a) KaWASUMI's treatise and construction of disaster prevention bases

With heavy damage as a result of the Isewan Typhoon of 1959 as a starting point, the Basic Law for Disaster Prevention was issued in 1961. The law directed both national and local governments to establish the Disaster Prevention Council. The TMG established its Council in 1962.

The Tokyo Metropolitan Disaster Prevention Council suggested that countermeasures for an earthquake event were urgently required. The Council's suggestion was based upon the "69 
year periodicity" presented by KAWASUMI (1970), who was the first chairman of the Sub-council for Earthquake Disaster Prevention. According to Kawasumi's treatise, Kamakura City, Kanagawa Prefecture, will experience a serious earthquake between 1978 and 2004.

The supposition at that time was that there would be a recurrence of earthquakes to the magnitude of the 1923 Great Kanto Earthquake. It was accepted that Tokyo would be severely damaged along with Kamakura City. Also, because fires were a main cause of catastrophic damage in the Great Kanto Earthquake, countermeasures for fires were considered to be most important. Accordingly, construction of disaster prevention bases was planned to secure safe refuge against fires. Also, the TMG designated 42 refuge bases in the 23 ward area in 1968 and added another four in 1970.

The RPKD was announced in 1969. At that time, the Koto District was regarded as one of the most dangerous districts for an earthquake disaster. Wooden houses had been densely built on soft deposits and were interspersed with factories using combustible materials, ground height of the eastern part was lower than the sea level, and heavy traffic congestion was an everyday affair. Also, air and water pollution were increasing as problems. Urgent improvement in living conditions and natural disaster countermeasures were deemed.

Construction of 6 disaster prevention bases was the main project in the RPKD (Fig. 4). Each disaster prevention base is planned to have an area of 50-100 ha and secure open spaces where all residents in the Koto District can take refuge within 30 minutes (Table 3). Distance from the living place to one of the disaster prevention bases is less than $3 \mathrm{~km}$.

Although 6 disaster prevention bases were planned, construction work has been completed for only the Shirahige Higashi Base. A built-up area redevelopment project and a fireproofing promotion project have been undertaken in the other base areas. But for the Yotsugi (Higashi and Nishi) Base, only planning has been undertaken.

The Shirahige Higashi Base is about $1,600 \mathrm{~m}$ in length and $200-300 \mathrm{~m}$ in width. Its total area is 37.9 ha, of which 10.3 ha has been prepared for parks, sports grounds and other open spaces. These open spaces will be used as a refuge area in an emergency. The planned capacity of the refugee is 80,000 .

Apartment blocks of thirteen stories high have been built. They have been connected to each other and form a continuous fire-prevention barrier of about $1,500 \mathrm{~m}$ in length and about $40 \mathrm{~m}$ in height. The apartments have been equipped with fireproof shutters, drenchers, etc. (TMG, 1985).

Together with installations for the disaster concerned, those for daily life (shops, schools, nurseries and meeting places) have been constructed to serve the residents of apartments. Before the development of the Base, two big factories occupied the northern and southern parts of the area, several small factories were interspersed with wooden dwelling houses, and population was 1,860 . These buildings were pulled down and a disaster-proof living zone (mentioned later) was established. Now, about 7,000 people live in the apartments.

b) Legislation of the Tokyo Earthquake and Fire Prevention Ordinance (TEFPO)

It is essential for the reduction of earthquake damage to adopt comprehensive countermeasures, including not only earthquake-resistant construction, but also landuse management, forecast and warning, insurance, etc. (WHITE and HAAs, 1975). Tokyo, however, is so over-populated that it is hardly possible to adopt countermeasures such as landuse management or building regulation. It is a more realistic approach in Tokyo to take countermeasures on the basis of the regional differences in predicted earthquake damage.

The Tokyo Metropolitan Assembly legislated the TEFPO in 1971. This Ordinance made it compulsory for the TMG to carry out a survey on the degree of danger in the region and to announce the results of the survey.

The results of survey were announced in 1975. As expected, the central part of the Tokyo Lowland was regarded as the most dangerous area. But similar dangerous areas were also to be found between the no. 6 and no. 7 arterial ring roads in the Yamanote Upland, where the population was dense and wooden houses were built close together. The results identified that 
Table 3. Disaster prevention bases in the Koto District

\begin{tabular}{|c|c|c|c|c|}
\hline \multicolumn{2}{|c|}{ Name of Base } & \multirow{2}{*}{$\begin{array}{c}\begin{array}{c}\text { Area of Base } \\
\text { (ha) }\end{array} \\
37.9 \\
57.9\end{array}$} & \multirow{2}{*}{$\begin{array}{c}\begin{array}{c}\text { Area of Refuge } \\
\text { (ha) }\end{array} \\
10.3 \\
11.6\end{array}$} & \multirow{2}{*}{$\begin{array}{c}\begin{array}{c}\text { Planned Capacity } \\
\text { for Refugees }\end{array} \\
80,000 \\
120,000\end{array}$} \\
\hline Shirahige & $\begin{array}{l}\text { Higashi } \\
\text { Nishi }\end{array}$ & & & \\
\hline \multicolumn{2}{|c|}{ Yotsugi (Nishi, Higashi) } & 88.1 & 44.1 & 230,000 \\
\hline \multicolumn{2}{|l|}{ Ryogoku } & 47.5 & 5.3 & 53,000 \\
\hline Chuo & $\begin{array}{l}\text { Sumida } \\
\text { Sarue }\end{array}$ & $\begin{array}{l}94.5 \\
53.0\end{array}$ & $\begin{array}{l}18.1 \\
17.4 \\
\end{array}$ & $\begin{array}{l}139,000 \\
110,000 \\
\end{array}$ \\
\hline \multicolumn{2}{|c|}{ Kameido-Ojima-Komatsugawa } & 114.1 & 22.6 & 200,000 \\
\hline \multicolumn{2}{|l|}{ Kiba } & 75.8 & 24.2 & 150,000 \\
\hline \multicolumn{2}{|c|}{ Total } & 568.8 & 153.6 & $1,082,000$ \\
\hline
\end{tabular}

Locations are shown in Fig. 4.

Data source: Tokyo Metropolitan Government (1986).

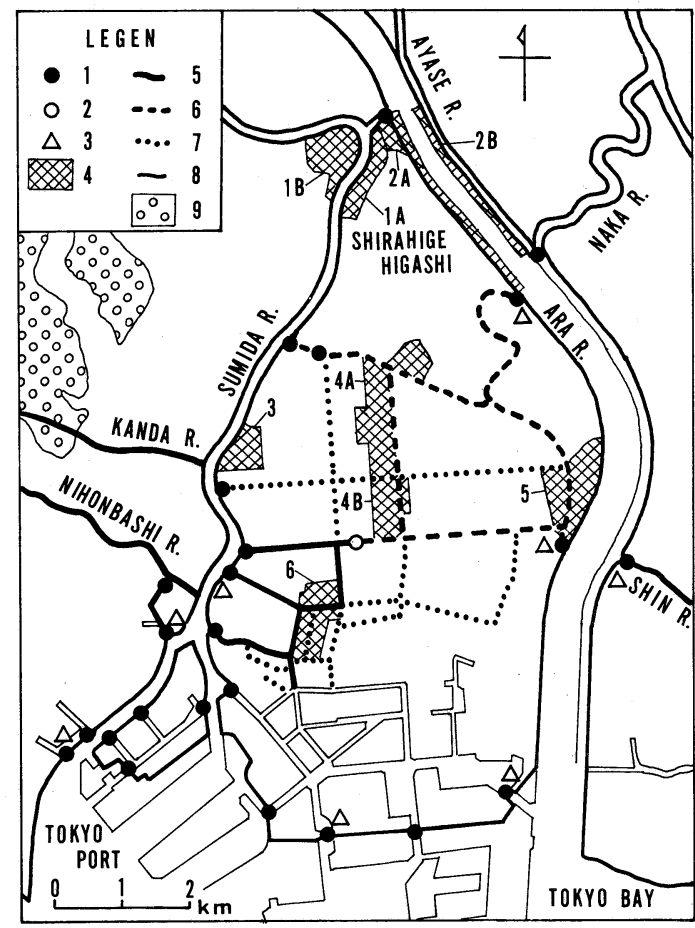

Figure 4.. Countermeasures undertaken in the Koto District and its suroundings.

1: Water gates; 2: Lock gates; 3: Draining sites; 4: Disaster prevention bases; 5: Rivers and canals equipped with earthquake-proof walls; 6 : Rivers and canals where the water level was lowered; 7: Filled-in canals or changed to culverts; 8: High waterbreaks and strengthened river banks (gaikaku teibo); 9: Yamanote Upland.

Disaster prevention bases - 1A: Shirahige Higashi; 1B: Shirahige Nishi; 2A: Yotsugi Nishi; 2B: Yotsugi Higashi; 3: Ryogoku; 4A: Chuo Sumida; Chuo Sarue; 5: Kameido-Ojima-Komatsugawa; 6: Kiba. countermeasures for fires were necessary for not only the Tokyo Lowland but also the Yamanote Upland.

c) Disaster-proof city planning

Based on the results of the survey on the degree of danger in the region, the TMG drew up the basic Plan for Urban Disaster Prevention Facilities (BPUDPF) in 1981, to push forward development of a disaster-proof city. The policy adopted in this basic plan was not to secure safe refuge against fires, but to make evacuation unnecessary.

Three points are given attention in development of a disaster-proof city (TMG, 1986). They are as follows:

a: Disaster-proof city planning should be based on security, but it should be suited to comfortableness and convenience which are necessary for daily life;

b: Functions for disaster prevention should be provided not only with works appropriate to disaster prevention, but also with those for longterm urban development and other improvement works for urban facilities;

c: Works for disaster prevention should be carried out together with measures for the community.

Works for an emergency should fit in with everyday life. At the same time, it is necessary to create a community which secures its own safety by itself. To realize these measures, creation of disaster-proof living zones was en- 
couraged.

Because development of a disaster-proof city would take several decades, two practical plans are suggested in the BPUDPF. One is construction of firebreaks to prevent fires from spreading. The other is improvement of a refuge plan. Also, creation of disaster-proof living zones is recommended.

A network of firebreaks is composed of roads, railways, rivers and parks. Necessary fireproof measures can be carried out along firebreaks. For example, buildings along the both sides of a road are reconstructed to be fireproof. Firebreaks divide the 23 ward area into 700 blocks. Each comprises a disaster-proof living zone which roughly covers an elementary schools or junior high school district. Development of parks and public squares, consolidation of minor roads and improvement of the living environment are carried out in each disaster-proof living zone. Residents are expected to combat disaster as well as to prevent an outbreak of fire.

The refuge plan for a major fire is comprised of a refuge base plan and designation of a refuge base for people. Roads and bridges to refuge bases have been improved and fireproof measures have been taken around refuge bases. The refuge plan is revised about every five years because of changes in conditions in the city. Though 137 refuge bases have now been designated in the 23 ward area, a number of people would have to walk more than $3 \mathrm{~km}$ to a refuge base in an emergency situation. Securing open spaces, further construction of new refuge bases is seen as necessary.

\section{CONCLUDING REMARKS}

Vulnerability for natural disasters depends on both natural and social conditions and is affected by preparedness for extreme natural events. The Tokyo Lowland has suffered from natural disasters several times due to such natural condition as: low ground height and thick soft deposits. As well land subsidence made countermeasures for natural disaster prevention more difficult and intensive landuse was likely to increase the amount of damages.

On the other hand, investment in natural disaster prevention has had the effect of decreas- ing damages. The drainage canals prevented big rivers from flooding and the "gaikaku teibo" pushed back storm surge. The likelihood of a flood disaster has been decreased considerably, but that of earthquake disasters has yet been remained.

There are two problems that need to be examined in the practical plans adopted in the disaster-proof city planning. One is that the main countermeasures for earthquakes include redevelopment of built-up areas and the construction of fireproof buildings. These works promote very intensive landuse and a high population density. Although construction of fireproof buildings for housing must be promoted, it is essential that an increase in damage potential has to be discouraged.

The other is concerned with the refuge plan. Because refuge from fires is affected by the conditions of breakout and the spread of fires, it would be difficult to designate refuge bases for people on the basis of their living place. It is possible that many people will not take refuge in a designated refuge base, but will go to whichever one they personally select.

Artificial changes to the natural conditions done through landuse proceed irreversibly. Their effects are likely to be taken over a long period of time. This is proved by the history of countermeasures for natural disasters on the Tokyo Lowland. That is, the present improvement works for natural disaster prevention are planned to get over conditions which the Tokyo Lowland was burdened with in the past.

(Received Oct. 31, 1989)

(Accepted Jan. 31, 1990)

\section{References}

Imperial Earthquake Investigation Committe (1925a): Report of the Imperial Earthquake Investigation Committee, 100A, Iwanami Shoten, Tokyo, 353 p. (JE)

Imperial Earthquake Investigation Committee (1925b): Reports of the Imperial Earthquake Investigation Committee, 100E, Iwanami Shoten, Tokyo, 296 p. (JE)

IsHi, M., ENDO, T., SAITO, K., et al. (1988): Land subsidence due to groundwater withdrawal, 1987. Ann. Rept. Inst. Civil Engin. Tokyo Metro. Gov't., $155-191$. (J)

KaizUKa, S., NARuse, Y. and MATSUdA, I. (1977): Recent formations and their basal topography in and 
around Tokyo Bay, central Japan. Quaternary Research, 8, 32-50.

KaWASUMI, H. (1970): Proofs of 69 year periodicity and imminence of destructive earthquake in southern Kanto and problems in the countermeasures thereof. Journ. Geogr. (Tokyo), 79, 115-138. (JE)

MATSUDA, I. (1974): Distribution of the Recent deposits and buried landforms in the Kanto Lowland, central Japan. Georgr. Repts. Tokyo Metrop. Univ., no. 9, $1-36$.

MATSUDA, I. (1984): An introductory note on earthquake damage and measures. Geogr. Repts. Tokyo Metrop. Univ., no. 19, 209-216.

MATSUURA, S. (1989): Kokudo no Kaihatsu to Kasen (Development of National Land and Rivers). Kajimashuppan, Tokyo, 268 p. (J)

Ministry of Construction (1985): Sogo Chisui Kanren Deta Shu (Data Concerning the Integrated Flood Prevention). Research Data of Public Works Research Institute, Ministry of Cosntruction, no. 2158, 113 p. (J)

NAKANO, T. and MATSUDA, I. (1976): A note on land subsidence in Japan. Geogr. Repts. Tokyo Metrop. Univ., no. 11, 147-161.

NAKANO, T. and MATSUDA, I. (1984): Earthquake damage, damage prediction and countermeasures in Tokyo, Japan. Ekistics, no. 308, 415-419.

NAKANO, T., Kadomura, H. and Matsuda, I. (1969): Land subsidence in the Tokyo Lowland. Geogr. Repts.
Tokyo Metrop. Univ., no. 4, 33-42.

TAJime, T., MochizUKI, T. and MATsUda, I. (1977): Jiban to shingai (Ground conditions and earthquake damage). Maki-shoten, Tokyo, 258 p. (J)

TAKEMI, Y. (1930): Distribution of factories in Great Tokyo. Geogr. Rev. Japan, 6, 369-386. (J)

Tokyo Metropolitan Government (1973): Takashio (Storm Surge). 45 p.

Tokyo Metropolitan Government (1976): First step toward a city where damage from disasters can be minimized. Tokyo Municipal News, 26(2), 1-3.

Tokyo Metroplitan Government (1981): Toshi Bosai Shisetsu Kihon Keikaku (The Basic Plan for Urban Disaster Prevention Facilities). 116 p. (J)

Tokyo Metropolitan Government (1985): Koto Bosai Kyoten Shirahige Higashi Chiku Jigyo no Gaiyo (A Summary of Works Carried out in the Shirahige Higashi Disaster Prevention Base). 10 p. (J)

Tokyo Metropolitan Government (1986): Tokyo-to $n i$ Okeru Bosai Toshi Zukuri no Gaiyo (A Summary of Disaster-Proof City Planning in Tokyo). 132 p. (J)

Tokyo Metropolitan Government (1987): Teichi no Kasen (Rivers in the Lowland). 49 p. (J)

UsAMI, T. (1976): History of disastrous earthquakes in Edo (Tokyo). Bull. Earthq. Res. Inst. 51, 231-250. (JE)

White, G. and HAAS, J.E. (1975): Assessment of Research on Natural Hazards. MIT Press, Cambridge, $487 \mathrm{p}$. 


\section{東京低地における自然災害と対策}

松田磐余*

東京低地は, 低平でかつ軟弱地盤が厚く堆積している。 この低地の土地利用は, 江戸時代までは隅田川沿いに市 街地が立地していた他は，農業に利用され，そこでは水 害はある程度許容されていた。明治時代以降の工業化 は，水害を許容できない土地利用を展開し，荒川放水路 の建設を促した。また，地下水の過剩揚水により，地盤 沈下を発生させ， 0メートル地帯を誕生させた。0メ一 トル地帯は, 現在 $68 \mathrm{~km}^{2}$ に達している。災害に対して脆 弱な条件を元来持っていたら党に，0メートル地帯の発 生は，東京低地に和ける災害対策を一層困難にした。

東京に大被害をもたらした地震には，直下地震とプレ 一ト境界に発生する大規模な地震がある。前者の例は安 政江戸地震 (1855年) で, 後者の例は関東地震 (1923年) である。関東地震では同時に多発した火災による被害が 著しかったので，現在の地震対策では火災対策が重要視 されることになった。水害には, 大河川の汇濫, 高潮, 内水汇濫，がある。さらに，地震による堤防の決壊など により惹起される水害も予想される。

東京都では災害対策を，長期的な都市計画や環境整備
計画に取り込みながら進めてきた。なかでも代表的なの は江東デルタ地帯での取り組みである。地震に対しては 6 つの防災拠点が計画され，白髭東地区では完成し，他 の地区でも事業が着手されている。防災拠点では, 避難 地としての機能が備えられる上に，日常生活でも良好な 環境が整備され，災害に対して備えをもったコミュニテ 1の育成が行われている。水害に対しては，外郭堤防 や，排水機場の建設が行われると共に，内部河川の改修 が進められている。不要な河川は埋め立てられたり暗渠 化されて，オープンスペースとして活用されているし， 有用な河川の両岸には耐震護岸が建設されている。

自然災害への脆弱性は，土地自然に求められやすい が，土地利用や災害対策と深い関わりを持つことは言う までもない。本論では，東京低地の自然的条件，土地利 用の展開，自然災害，㷋害対策の歷史を概観しながら， 前の時代に行われた自然の改変や土地利用が，次の時代 の都市改良や災害対策の初期条件となっていく過程を明 らかにした。

* 个158 東京都世田谷区深沢 東京都立大学理学部 